\title{
GEOQUÍMICA E MINERALOGIA DOS DEPÓSITOS ALUVIAIS NA BACIA DO RIACHO DO TIGRE, SEMIÁRIDO PARAIBANO
}

\author{
Adonai Felipe Pereira de Lima Silva* \\ Universidade Federal da Paraíba
}

\section{Jonas Otaviano Praça de Souza**}

Universidade Federal da Paraíba

Resumo: O Déficit hídrico no semiárido brasileiro constitui um problema tanto de ordem econômica quanto em relação à qualidade da água e à saúde humana. Nesse sentido, a análise dos sedimentos ganha importância para os planejamentos ambientais, por ser destino final dos metais pesados poluentes e dos sais solúveis contidos nas águas subterrâneas ou superficiais. Desse modo, a presente pesquisa consistiu em analisar as características geoquímicas e mineralógicas dos depósitos aluviais da Bacia Riacho do Tigre - PB, como a variedade e ocorrência de determinados elementos químicos e minerais identificados nas amostras, utilizando as técnicas de Fluorescência de Raios X (FRX) e Difração de Raios X (DRX). Foram coletadas amostras de cinco pontos de análise, que tiveram como critério de escolha a proximidade do trecho aluvial com poços rasos utilizados pela comunidade local, visto a possibilidade de contaminação do aquífero via sedimento em diferentes unidades. Os resultados indicaram que a maior variedade de minerais identificados corresponde ao trecho 1 e principalmente ao trecho 3 , sendo único ponto onde houve identificação de metal pesado, o crômio. Os trechos 2 e 4 obtiveram predominância absoluta de minerais compostos essencialmente por óxido de silício, como o quartzo e seus polimorfos tridimita (no trecho 2) e cristobalita (no trecho 4). No trecho 5 a sílica corresponde somente ao quartzo e também foi possível identificar outro mineral, que é a magnetita, apesar de apresentar pico de difração com baixa intensidade. Os minerais identificados coincidem com as características geológicas, litoestratigráficas e litológicas da bacia Riacho do Tigre.

Palavras-chave: Terras secas; Geoquímica ambiental; Depósitos Aluviais.

\section{GEOCHEMISTRY AND MINERALOGY OF ALLUVIAL DEPOSITS IN THE RIACHO DO TIGRE BASIN, SEMI-ARID REGION OF THE PARAÍBA}

Abstract: The water deficit in the Brazilian semi-arid region is a problem both in terms of economics and concerning water quality and human health. In this sense, sediment analysis gains importance for environmental planning, as it is the final destination of polluting heavy metals and soluble salts contained in groundwater or surface water. This research consisted of the geochemical and mineralogical analysis of the alluvial deposits of the Riacho do Tigre Basin - PB, such as the variety and occurrence of specific chemical and mineral elements identified in the samples, using the techniques of X-Ray Fluorescence (FRX) and X-Ray Diffraction (XRD). Samples were collected from five points of analysis, selected by the proximity of the alluvial section with shallow wells used by the local community, considering the possibility of contamination of the aquifer by sediment in different units. The results indicated that the widest variety of minerals on sections 1 , and 3 , the only point with traces of heavy metal, chromium. On sections 2 and 4 showed a predominance of silicon oxide minerals, such as quartz, tridymite (in section 2) and cristobalite (in section 4). In section 5 , silica corresponds only to quartz, and it was also possible to identify another mineral, which is magnetite, despite having a diffraction peak with low intensity. The identified minerals coincide with the lithological characteristics of the Riacho do Tigre basin.

Keywords: Dryland; Environmental Geochemistry; Alluvial Deposits.

\section{GEOQUÍMICA Y MINERALOGÍA DE DEPÓSITOS ALUVIALES EN LA CUENCA DEL RIACHO DO TIGRE, REGIÓN SEMIÁRIDA DE PARAÍBA}

Resumen: El déficit de agua en la región semiárida brasileña es un problema tanto en términos económicos como en relación con la calidad del agua y la salud humana. En este sentido, el análisis de sedimentos cobra importancia para la planificación ambiental, ya que es el destino final de los metales pesados contaminantes y las sales solubles contenidos en las aguas subterráneas o superficiales. Así, la presente investigación consistió en analizar las características geoquímicas y mineralógicas de los depósitos aluviales de la Cuenca del Riacho do Tigre - PB, como la variedad y ocurrencia de ciertos elementos químicos y minerales identificados en las muestras, utilizando técnicas de Fluorescencia de Rayos X (FRX) y Difracción de Rayos X (XRD). Se recolectaron muestras de cinco puntos de análisis, que tuvieron como criterio de selección la proximidad del tramo aluvial con pozos poco profundos utilizados por la comunidad local, dada la posibilidad de contaminación del acuífero vía sedimento en diferentes unidades. Los resultados indicaron que la mayor variedad de minerales identificados corresponde al tramo 1 y principalmente al tramo 3 , siendo el único punto donde se identificó el metal pesado, el cromo. Los tramos 2 y 4 tuvieron un predominio absoluto de minerales compuestos esencialmente por óxido de silicio, como el cuarzo y sus polimorfos tridimita (en la sección 2) y cristobalita (en la sección 4). En la sección 5, la sílice corresponde solo al cuarzo y también se pudo identificar otro mineral, que es la magnetita, a pesar de tener un pico de difracción de baja intensidad. Los minerales identificados coinciden con las características geológicas, litoestratigráficas y litológicas de la cuenca del Riacho do Tigre.

Palabras clave: Secano; Geoquímica ambiental; Depósitos aluviales.

*Mestre e Doutorando em Geografia pela Universidade Federal da Paraíba. Professor de Geografia lotado na Prefeitura Municipal de Conde-PB. E-mail: ad.felipelima@hotmail. com. ORCID: https://orcid.org/0000-0002-1654-6775.

**Geógrafo. Doutor em Geografia. Professor adjunto do Centro de Ciências Exatas e da Natureza, do Departamento de Geociência da Universidade Federal da Paraíba. E-mail: jonasgeoufpe@yahoo.com.br. ORCID: https://orcid.org/0000-0002-1405-0944. 


\section{Introdução}

A Geoquímica Ambiental é uma ciência ambiental que consiste em estudar os processos químicos da antroposfera, analisando os problemas ambientais em relação aos elementos naturais e sociais, e assim poder gerar informações úteis visando a melhoria da qualidade de vida dos atores sociais envolvidos e a conservação dos recursos naturais (ROHDE, 2013).

Dentre os problemas ambientais, o que tem sido recorrente em áreas com déficit hídrico é a salinização dos solos e águas, impulsionados muitas vezes por atividades antropogênicas, como a prática de irrigação quando não manejada adequadamente, provocando alterações nas propriedades físico-químicas do solo e das reservas hídricas. Os sais solúveis contidos nas águas (subterrâneas e superficiais) podem, em certas condições (clima e lugar), salinizar os solos com produtos solúveis, afetando o regime de umidade do solo e nutrição e desenvolvimento vegetativo das plantas. Diversos fatores contribuem para a salinização das águas subterrâneas no nordeste brasileiro, como o clima, modo de ocorrência das águas (aquíferos livres ou confinados), condições de circulação e natureza geológica, no entanto, um dos principais indicadores de salinidade das águas subterrâneas é o tipo de solo e a exposição à evaporação (NUNES FILHO, et al., 2000).

Inserido na dinâmica fluvial dos recursos hídricos, os sedimentos são resultantes dos processos de intemperismo sob rochas que compartimentam o vale dos rios. Em vários países do mundo os sedimentos são analisados como indicador de qualidade ambiental de mananciais, contribuindo para melhoria da gestão, planejamento e políticas públicas nas esferas ambiental e governamental (GUEDES, 2012).

Os sedimentos fluviais têm se tornado objeto de estudo de várias pesquisas de cunho ambiental, devido à presença de contaminantes em meio às suas partículas, muitas vezes ocasionadas por intervenções antrópicas. Dessa forma, os sedimentos têm se tornado o destino final de fixação de fontes poluidoras, principalmente os metais pesados. A análise dos sedimentos é fundamental para a preservação, avaliação de poluição e monitoramento da qualidade dos recursos hídricos, visto que se configuram como o destino de muitos elementos químicos solúveis e insolúveis, gerando influência sobre sistemas aquáticos. Portanto, uma maneira realista de analisar a contaminação dos metais pesados em água é justamente através da análise dos sedimentos, pois estes refletem a situação cronológica da situação ambiental no local da coleta, enquanto que a coleta de água indica a presença do metal apenas no momento da coleta (ARAÚJO et al., 2017).

A qualidade dos sedimentos - que antes era vista apenas como acumulador de nutrientes e de contaminantes - passa a ser analisada a partir dessa nova ótica, devido a sua importância nas relações de interação com a coluna d'água e com a biota residente. Uma tendência observada é que quanto menor as partículas de sedimento (silte e argila), maiores são as concentrações de contaminantes, isso ocorre pelo fato de as pequenas partículas terem grandes áreas da superfície para adsorção (CAMPOS e DALL'OCCO, 2011). A geologia da área, o tipo de vegetação, uso/ocupação da área, presença de mineralizações e o regime hidrológico são alguns fatores que influenciam na variação de concentração de elementos químicos nos sedimentos (CORINGA et al., 2013).

Os processos biológicos, físicos ou químicos que influenciam o metabolismo do sistema ocorrem nos sedimentos, contendo concentrações de elementos químicos superiores à coluna d'água. Além disso, são nos sedimentos que se depositam todos os compostos e estruturas animais e vegetais que não foram decompostos integralmente. Desse modo, o sedimento pode ser compreendido como um dos elementos mais importantes do ecossistema aquático no que se refere à ciclagem de matéria e fluxo de energia (PIRES et al., 2001). Sendo assim, é essencial a análise dos sedimentos aluviais retidos no leito e nas planícies dos sistemas fluviais para avaliar os impactos que possam comprometer a saúde e qualidade de vida das presentes e futuras gerações.

Diante dessas informações, a presente pesquisa consistiu em analisar as características geoquímicas e mineralógicas dos depósitos aluviais de uma bacia hidrográfica em ambiente semiárido, utilizando as técnicas de Fluorescência de Raios X (FRX) e Difração de Raios X (DRX) em amostras coletadas dos sedimentos provenientes do leito e/ou das planícies das drenagens.

\section{A área de estudo}

A área de pesquisa se localiza na bacia hidrográfica Riacho do Tigre, com aproximadamente $560 \mathrm{~km}^{2}$, situada no município de São João do Tigre - PB (figura 1). 


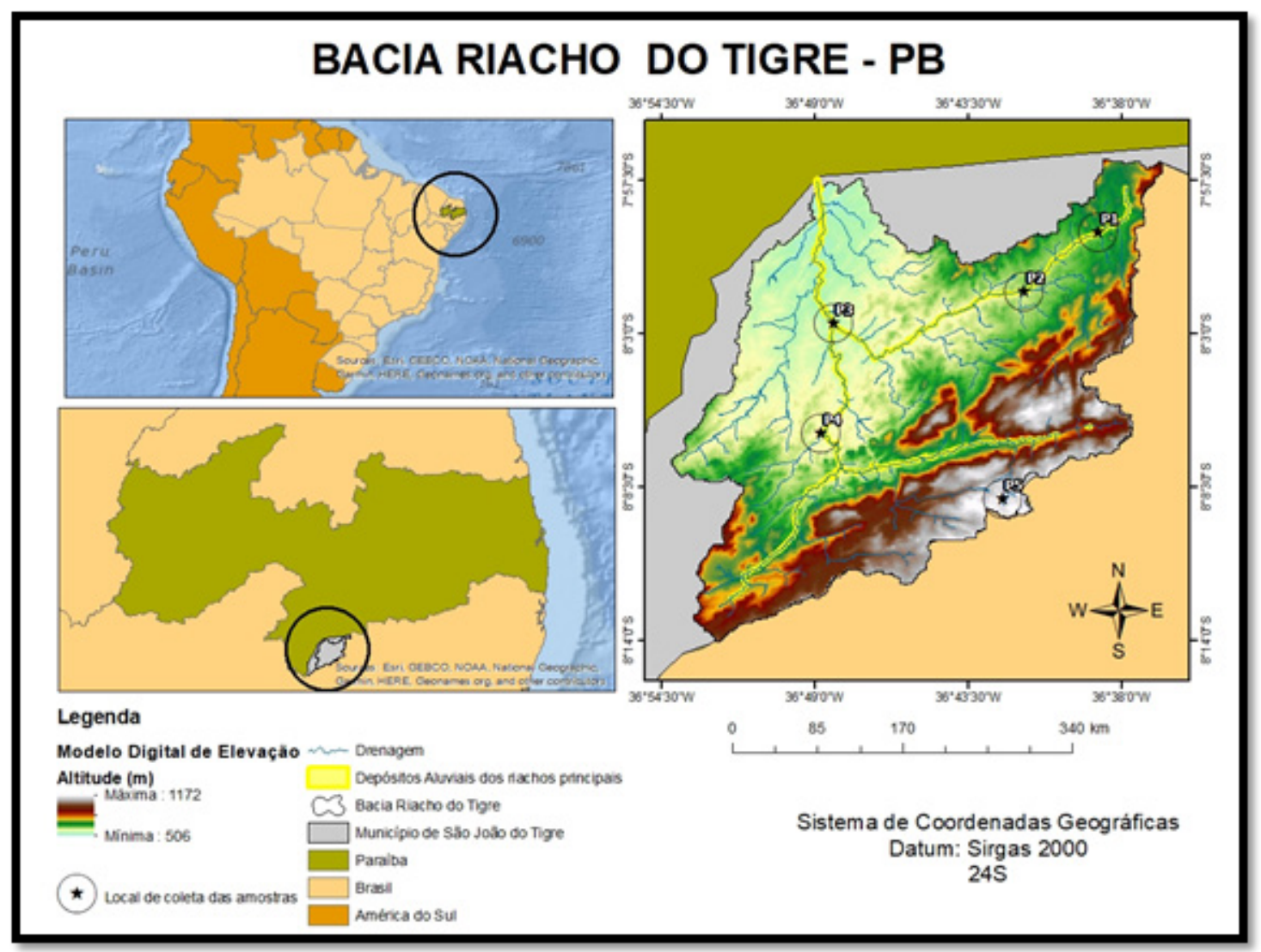

Fonte: Elaborado pelos autores

A bacia Riacho do Tigre possui certa variação de altitude e declividade, com mais intensidade na porção sudeste: a altitude varia entre 506 m e 1772 m, na qual a parte mais elevada se encontra no sudeste da bacia. Já a declividade pode haver variação de $0 \%$ a $114,7 \%$, sendo os maiores índices encontrados entre duas serras, que são as serras do Paulo e mais ao sul a serra de Santa Maria. Acerca da unidade de relevo, o município de São João do Tigre está completamente inserido no Planalto da Borborema.

Emrelaçãoàcompartimentaçãomegageomorfológica do Planalto da Borborema, a parte mais elevada de São João do Tigre está situada na zona dos Maciços Remobilizados do Domínio da Zona Transversal, enquanto que a parte baixa está na Depressão Intraplanáltica Paraibana. Essas áreas apresentam evidências de ciclos de erosão que atingiram grande parte do sertão nordestino. 0 controle estrutural da área influencia em outros elementos, como: os rios, que não avançam além da escarpa oriental que delimita o planalto; e o clima, reduzindo o grau de temperatura na medida em que superfície se encontra mais alta, causando também a diferenciação de temperatura de vertentes a barlavento e a sotavento. A influência da estrutura geológica se deve às rochas cristalinas (figura 2), que são mais resistentes à erosão em relação aos outros tipos de rochas de áreas adjacentes, configurando o relevo ondulado da Borborema (CORRÊA et al., 2010).

Os rios da bacia são intermitentes, típicos deambientes fluviais semiáridos com vazão ausente durante maior parte do ano, tendo em média menos de 40 dias de fluxo por ano. Contudo, não há dados observados, sendo que essa é a média padrão para canais de ordem semelhante na região (SILVA e SOUZA, 2017). O bioma é a caatinga, apresentando como vegetação predominante a Caatinga Hiperxerófila com presença de alguns trechos de Floresta Caducifólia. 0 clima é Tropical Semiárido, com chuvas de verão nos períodos entre novembro e abril e apresentando pluviosidade média anual de 431,8mm (CPRM, 2005; IBGE, 2016).

Vasconcelos e Souza (2016) definiram cinco tipos de unidades de paisagem para a bacia Riacho do Tigre, baseadas em aspectos a partir das variáveis encontradas no local, como os solos, relevo, declividade, geologia e uso e cobertura do solo. As unidades constituem os Pedimentos, os Pé de Serras, as Encostas Íngremes, as áreas de Cristas e as áreas de Topo Plano (VASCONCELOS e SOUZA, 2016). 
Nos Pedimentos a superfície é plana na maior parte da área, com baixa altitude e declividade máxima de $8 \%$, apresentando predominância de Neossolos Litólicos Eutróficos e Luvissolos Crômico, além de haver geologia composta de Metagranito, Metamonzonito, Metassienito, Metatonalito, Ortognaisse, Granitos e Granodioritos. As áreas de Pé de Serras estão localizadas próximas as Encostas Íngremes, apresentando declividade entre 8\% e $20 \%$, formação geológica composta de Metagranito, Metagranodiorito, Granito e Granodiorito e predominância de Neossolos Litólicos. As Encostas Íngremes possuem grau de declividade muito alto, com predominância de Neossolos Litólicos Eutróficos e geologia composta por Granito, Granodiorito, Monzofranito, Metagranito e Metagranodioritos. As Cristas possuem grande variação de declividade, com predominância de Neossolos Litólicos Eutróficos no geral e presença de Luvissolos Crômico na porção do sudoeste, além de geologia composta por Granitos e Granidioritos no geral e Metadacitos, Metapelito, Paragnaisse, Quartzo e rochas Metavulcânicas nas Cristas do sudoeste. Nas unidades de Topo Plano é possível encontrar Neossolos Regolíticos e Neossolos Litólicos Eutróficos, a declividade varia entre $8,1 \%$ a $20 \%$ e a geologia é dividida entre Metagranito, Metagranodiorito, Granito, Granodiorito e Monzogranito. No geral, a vegetação predominante em todas as unidades é a Caatinga Arbórea Arbustiva, com maior influência antrópica nos Pedimentos, Pé de Serras e Topo Plano (VASCONCELOS e SOUZA, 2016).

\section{Metodologia}

Para obter as informações referentes à geoquímica e mineralogia dos depósitos aluviais, foram realizados dois procedimentos metodológicos: a Espectrometria de Fluorescência de Raios X (FRX) e a Difração de Raios $X$ (DRX). A análise por FRX permite definir os elementos químicos das amostras a partir de óxidos, gerando informações pertinentes que, inclusive, podem servir de auxílio para identificação mais rápida e segura dos minerais por DRX. Já a análise por DRX permite a caracterização da composição mineralógica e fases cristalinas das amostras. Desse modo, as informações obtidas foram discutidas com base nos dados já existentes sobre a geologia e litologia da área de pesquisa, disponibilizados pelo Serviço Geológico do Brasil (CPRM, 2000, 2015).

Assim, as informações obtidas foram discutidas e relacionadas com os dados geológicos e litológicos já existentes para a área de pesquisa, que são os dados do Serviço Geológico do Brasil (CPRM) referentes aos Projetos Sumé (2000) e Pesqueira (2015), que correspondem aos estados da Paraíba e Pernambuco (Tabela 1). O Projeto Sumé abrange uma área que envolve o trecho 1 (unidade Granitóide de Serra da Barraca). Já o Projeto Pesqueira abrange uma extensa área que envolve os trechos 2 (unidade Suíte Intrusiva Metagranitóides Cariris Velhos); trechos 3 e 4 (unidade Complexo Riacho do Tigre); e o trecho 5 (unidade Suíte Intrusiva Itaporanga).

Tabela 1 - Unidades litoestratigráficas das localizações dos pontos de análise

\begin{tabular}{|c|c|c|c|}
\hline $\begin{array}{c}\text { UNIDADES } \\
\text { LITOESTRATIGRÁFICAS }\end{array}$ & $\begin{array}{l}\text { TRECHOS } \\
\text { NESTA } \\
\text { UNIDADE }\end{array}$ & $\begin{array}{c}\text { LITOLOGIA } \\
\text { (Algumas características) }\end{array}$ & $\begin{array}{c}\text { CARTA } \\
\text { GEOLÓGICA }\end{array}$ \\
\hline $\begin{array}{l}\text { GRANITÓIDE DE SERRA } \\
\text { DA BARRACA }\end{array}$ & P1 & $\begin{array}{l}\text { Litótipos quartzo-monzoníticos, } \\
\text { quartzo-dioríticos e leucograníticos, } \\
\text { e minerais ferromagnesianos. Estes } \\
\text { granitóides são constituídos } \\
\text { essencialmente por plagioclásio, } \\
\text { microclina, quartzo } \\
\text { e por vezes biotita. }\end{array}$ & $\begin{array}{l}\text { Projeto Sumé } \\
\text { (CPRM, 2000) }\end{array}$ \\
\hline $\begin{array}{c}\text { COMPLEXO RIACHO DO } \\
\text { TIGRE }\end{array}$ & $\mathrm{P} 3$ e $\mathrm{P} 4$ & $\begin{array}{l}\text { Biotita, granada, plagioclásio, } \\
\text { quartzo, piroxênio, anfibólio, xistos } \\
\text { granatíferos, gnaisses xistosos, } \\
\text { ortognaisses, paragnaisses, rochas } \\
\text { metavulcânicas e metamáficas. }\end{array}$ & $\begin{array}{c}\text { Projeto } \\
\text { Pesqueira } \\
\text { (CPRM, 2015) }\end{array}$ \\
\hline $\begin{array}{l}\text { SUITE INTRUSIVA } \\
\text { METAGRANITÓIDES } \\
\text { CARIRIS VELHOS }\end{array}$ & $\mathrm{P} 2$ & $\begin{array}{l}\text { Ortognaisses leucograníticos e } \\
\text { migmatitos de fonte crustal a } \\
\text { granada e biotita, sin-tangenciais, de } \\
\text { afinidade peraluminosa. }\end{array}$ & $\begin{array}{c}\text { Projeto } \\
\text { Pesqueira } \\
(\mathrm{CPRM}, 2015)\end{array}$ \\
\hline $\begin{array}{l}\text { SUITE INTRUSIVA } \\
\text { ITAPORANGA }\end{array}$ & P5 & $\begin{array}{l}\text { Rochas igneas plutônicas, rochas } \\
\text { monzograniticas; feições } \\
\text { magnéticas, anfibólios, minerais } \\
\text { com afinidade ao ferro, quartzo- } \\
\text { coríndon hiperstênio normativas e } \\
\text { biotita. }\end{array}$ & $\begin{array}{c}\text { Projeto } \\
\text { Pesqueira } \\
\text { (CPRM, 2015) }\end{array}$ \\
\hline
\end{tabular}

Fonte: Elaborado pelos autores. 
Os pontos de análise tiveram como critério de escolha a proximidade do trecho aluvial com poços rasos utilizados pela comunidade local, visto a possibilidade de contaminação do aquífero via sedimento em diferentes compartimentos do relevo, o que pode causar danos à saúde humana. Os poços se localizam no leito e/ou planícies dos trechos fluviais de onde foram extraídas as amostras. As amostras foram extraídas a cerca de 5 metros de distância à montante de cada poço.

\section{Fluorescência de Raios X (FRX)}

A análise por fluorescência de raios $X$ pode ser realizada para fins qualitativos ou quantitativos, que consiste na medição de intensidades de raios $X$ que são emitidos pelos elementos que constituem a amostra. Desse modo, a amostra é excitada por partículas (elétrons, prótons ou íons), sendo através de tubos de raios $X$ o processo mais utilizado. Por sua vez, os raios $X$ incidem nas amostras, estas que reagem emitindo linhas espectrais com energia específica dos elementos cujas intensidades estão relacionadas com a concentração. Desse modo, a análise por FRX pode ser definida em três fases: excitação dos elementos constituintes da amostra; dispersão dos raios característicos que são emitidos pela amostra; e detecção dos raios X (SANTOS et al., 2013).

Antes que as amostras fossem submetidas ao equipamento de análise de fluorescência de raios $X$, as mesmas foram maceradas com auxílio de pistilo e almofariz e peneiradas em uma peneira redonda de 200 mesh. 0 equipamento utilizado foi o XRF-1800 da SHIMADZU, disponível no Laboratório de Solidificação Rápida (LSR) do Centro de Tecnologia (CT) da Universidade Federal da Paraíba (UFPB).

Os resultados dessa análise permitem gerar dados qualitativos e quantitativos da composição química em forma de óxidos das amostras correspondentes aos cinco pontos de análise, determinando os tipos de óxidos e suas respectivas concentrações por porcentagem.

As informações geradas além de indicar os elementos químicos contidos em cada trecho - podendo ser identificada a presença de metais pesados que podem constituir risco de contaminação dos depósitos aluviais, que consequentemente, trazem risco à saúde humana - ainda contribuem para a identificação dos difratogramas, correspondentes à análise mineralógica por Difração de Raios X. A classificação dos tipos de metais pesados (poluentes) nos depósitos aluviais pode ser encontrada na Resolução do CONAMA n 344 , de 25 de março de 2004, que estabelece as diretrizes gerais e os procedimentos mínimos para a avaliação do material a ser dragado em águas jurisdicionais brasileiras.

\section{Difração de Raios X (DRX)}

De todas as técnicas de caracterização de materiais, a técnica de Difração de Raios X (DRX) se torna uma das técnicas mais indicadas - se não a mais indicada - para determinar a composição mineralógica e fases cristalinas presentes em argilominerais e material sedimentar no geral. A técnica funciona a partir da incidência de um feixe de raios $X$ em um cristal, que por sua vez esse cristal passa a interagir com os átomos presentes $\mathrm{e}$ originar o fenômeno da difração. A Difração de Raios $X$ instrumentaliza uma relação entre o ângulo de difração e a distância entre os planos que a originaram, esses planos que são característicos para cada fase cristalina (ALBERS et al., 2002), como se fossem impressões digitais correspondentes a cada tipo de mineral.

Nessa perspectiva, a Difração de Raios $X$ foi incorporada neste trabalho no intuito de contribuir para a caracterização e análise geoquímica dos depósitos aluviais da área de pesquisa. Desse modo, esse trabalho seguirá parcialmente a proposta metodológica da Embrapa (2009), seguindo também em partes a metodologia adotada por Melo (2014).

As amostras foram maceradas com auxílio de pistilo e almofariz e colocadas em uma lâmina de vidro de superfície plana, sob a forma de uma película fina e submetida à irradiação por raios $\mathrm{X}$ com varreduras de $5^{\circ}$ a $80^{\circ} \mathrm{em} 2 \theta \mathrm{com}$ velocidade de $2^{\circ} / \mathrm{min}$. A intensidade de difração dos raios emitidos foi determinada pelos diversos planos cristalinos dos minerais e representada em um difratograma. As análises foram realizadas no Laboratório de Combustíveis e Materiais (LACOM) do Centro de Ciências Exatas da Natureza (CCEN), no departamento de Química da Universidade Federal da Paraíba (UFPB). O processamento das amostras utilizou um difratômetro de raio $X$, da marca SHIMADZU, modelo Lab X/XRD-6000, com potência de 2 kVA, voltagem de $30 \mathrm{kV}$ e corrente de $30 \mathrm{~mA}$, com fonte de radiação CuKa $(\lambda=1,5406 \AA)$.

Em seguida, os valores obtidos foram trabalhados no software Crystallographica para identificação dos minerais das amostras, que é realizada por semelhança a partir do padrão difratométrico dos minerais contidos no banco de dados do ASTM (American Society for Testing and Materials).

Os resultados gerados por DRX consistem em identificar os tipos de minerais existentes nas amostras, podendo indicar e/ou explicar a origem da concentração 
de elementos químicos já identificados pela FRX.

\section{Resultados e discussão}

As análises geoquímicas e mineralógicas dos depósitos aluviais foram realizadas através das técnicas de Fluorescência de Raios X (FRX) e Difração de Raios X (DRX). Foram coletadas cinco amostras - uma amostra para cada ponto de análise, recebendo as denominações P1, P2, P3, P4 e P5, respectivamente - provenientes de depósitos aluviais (leito e/ou planícies das drenagens) com características diversas, tanto em relação a sua localização quanto às unidades de paisagem que as representam (figura 2).

Todos os pontos analisados ficam próximos de poços aluviais (cacimbas). As amostras de sedimento que podem ter ligações diretas - dinâmicas fluviais, processos de fluxo de transporte, infiltração, entre outras - com a água armazenada nos aquíferos livres daquela localidade. Esses aquíferos são explorados pela população residente, tanto para o uso doméstico quanto para a agricultura de pequena escala.

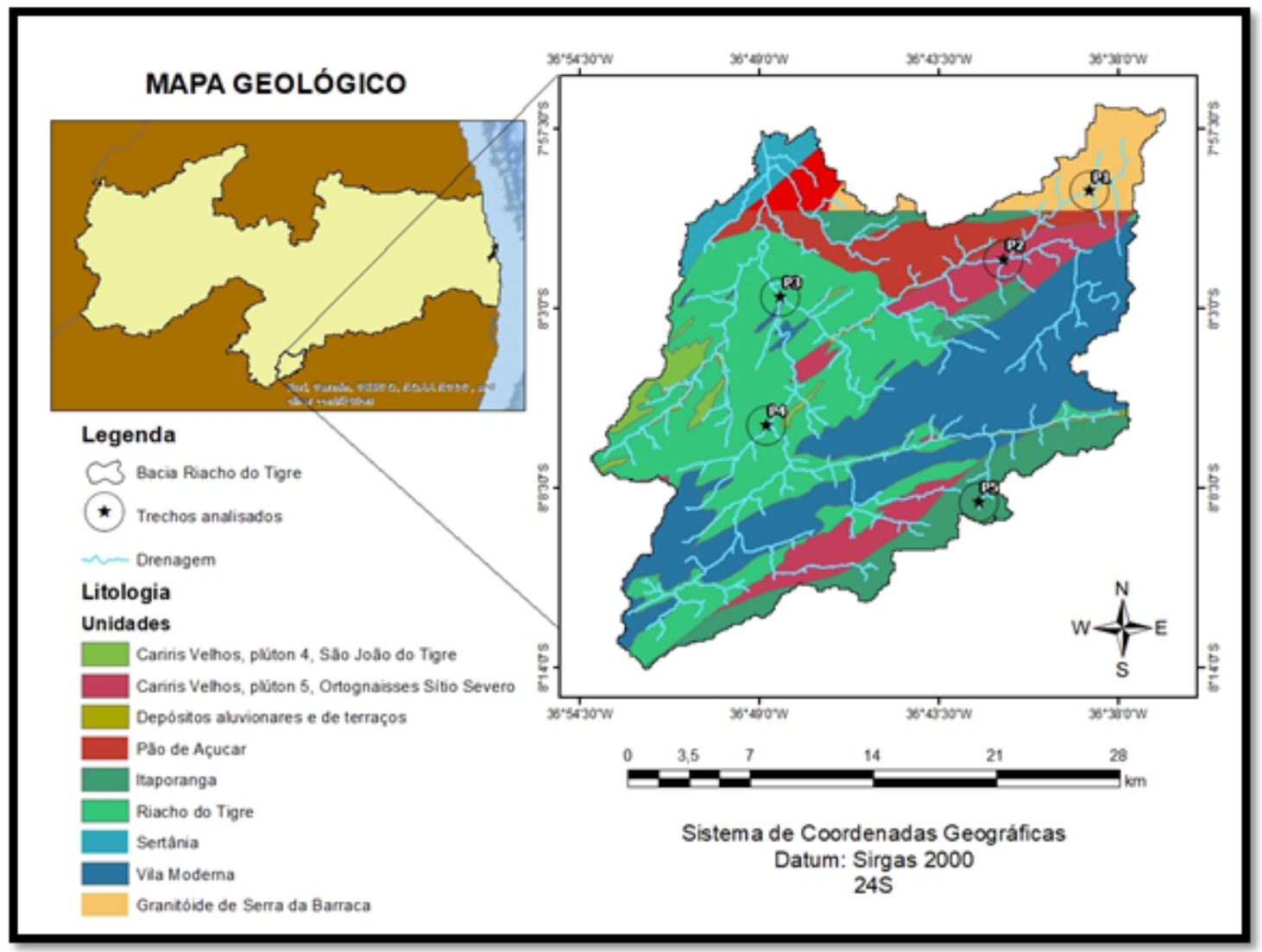

Fonte: Elaborado pelos autores.

Primeiramente, as amostras foram submetidas aos procedimentos de laboratório para a FRX, cujos resultados revelaram haver no total 13 tipos de óxidos silício $\left(\mathrm{SiO}_{2}\right)$, alumínio $\left(\mathrm{Al}_{2} \mathrm{O}_{3}\right)$, sódio $\left(\mathrm{Na}_{2} \mathrm{O}\right)$, ferro $\left(\mathrm{Fe}_{2} \mathrm{O}_{3}\right)$, potássio $\left(\mathrm{K}_{2} \mathrm{O}\right)$, bário $(\mathrm{BaO})$, titânio $\left(\mathrm{TiO}_{2}\right)$, estrôncio $(\mathrm{SrO})$, magnésio $(\mathrm{MgO})$, cálcio $(\mathrm{CaO})$, crômio $\left(\mathrm{Cr}_{2} \mathrm{O}_{3}\right)$, rubídio $\left(\mathrm{Rb}_{2} \mathrm{O}\right)$ e zircônio $\left(\mathrm{ZrO}_{2}\right)$ - somando todos os pontos, com maior variedade de elementos e quantidades em determinados pontos do que em outros. Os óxidos de silício, alumínio, sódio, ferro, cálcio e rubídio têm ocorrência em todos os pontos, porém, com variedades em proporção de quantidade, a exemplo desses dois últimos, que possuem valores de porcentagem abaixo de $1 \%$ (tabela 2). 
Tabela 2 - Quantidade em porcentagem dos elementos químicos nos trechos analisados

\begin{tabular}{|c|c|c|c|c|c|}
\hline $\begin{array}{c}\text { Elementos em } \\
\text { óxidos }\end{array}$ & P1 & P2 & P3 & P4 & P5 \\
\hline $\mathrm{SiO}_{2}$ & $81,4567 \%$ & $83,6437 \%$ & $82,2349 \%$ & $82,2972 \%$ & $88,0429 \%$ \\
\hline $\mathrm{Al}_{2} \mathrm{O}_{3}$ & $12,7317 \%$ & $10,4246 \%$ & $11,3023 \%$ & $11,3047 \%$ & $9,7090 \%$ \\
\hline $\mathrm{Na}_{2} \mathrm{O}$ & $1,8222 \%$ & $1,5433 \%$ & $2,4132 \%$ & $1,6652 \%$ & $0,4407 \%$ \\
\hline $\mathrm{Fe}_{2} \mathrm{O}_{3}$ & $2,0193 \%$ & $1,8660 \%$ & $1,3061 \%$ & $1,2394 \%$ & $1,2074 \%$ \\
\hline $\mathrm{K}_{2} \mathrm{O}$ & - & $1,3243 \%$ & $1,2171 \%$ & $2,4784 \%$ & - \\
\hline $\mathrm{BaO}$ & $0,6344 \%$ & $0,5193 \%$ & $0,6101 \%$ & $0,5524 \%$ & - \\
\hline $\mathrm{TiO}_{2}$ & $0,6540 \%$ & $0,3903 \%$ & $0,2831 \%$ & - & $0,3431 \%$ \\
\hline $\mathrm{SrO}_{\mathrm{MgO}}$ & $0,1351 \%$ & $0,1767 \%$ & $0,2010 \%$ & $0,1386 \%$ & - \\
\hline $\mathrm{CaO}_{\mathrm{Cr} 2} \mathrm{O}_{3}$ & $0,3302 \%$ & - & $0,1997 \%$ & $0,1777 \%$ & $0,1323 \%$ \\
\hline $\mathrm{Rb}_{2} \mathrm{O}$ & $0,1282 \%$ & $0,0722 \%$ & $0,1257 \%$ & $0,1159 \%$ & $0,0438 \%$ \\
\hline $\mathrm{ZrO}_{2}$ & - & - & $0,0767 \%$ & - & - \\
\hline & $0,0493 \%$ & - & $0,0301 \%$ & $0,0307 \%$ & $0,0281 \%$ \\
\hline
\end{tabular}

No entanto, foi possível perceber que a quantidade de $\mathrm{SiO} 2$ ficou acima de $80 \%$ em todos os pontos, assim como a quantidade de $\mathrm{Al}_{2} \mathrm{O}_{3}$ que ficou igual ou acima de $9 \%$, seguido de $\mathrm{Na}_{2} \mathrm{O}, \mathrm{Fe}_{2} \mathrm{O}_{3}$ e $\mathrm{K}_{2} \mathrm{O}$ com porcentagens entre $1 \%$ e $2 \%$, enquanto os demais óxidos tiveram porcentagem inferior a $1 \%$ em todos os pontos (tabela 2).

A quantidade grande de $\mathrm{SiO} 2$ pode estar relacionado à geologia da área pesquisa (figura 2), que de forma geral, é caracterizada litologicamente por afloramentos rochosos, como graníticos cristalinos (CPRM, 2015). Por sua vez, esses granitos são ricos em quartzo, feldspato alcalino e plagioclásio, cujas suas fórmulas químicas apresentam silício, alumínio e potássio (KOBAYASHI et al., 2017), podendo estar relacionado também com a quantidade de alumínio e potássio encontrada nos trechos analisados. Contudo, nos pontos localizados nas cabeceiras (P1 e P5) não foram identificadas a presença do potássio, cabendo uma investigação sobre essa observação em pesquisas futuras.

Os teores relativamente altos de sódio, no solo e na água, podem estar relacionados com a salinidade dos solos. Além do sódio contido na composição das rochas, o aumento de sódio no solo também pode estar atrelado aos processos naturais (áreas propensas a salinização), irrigação inadequada e uso inadequado de fertilizantes. Desse modo, o aumento de sódio também influencia em um $\mathrm{pH}$ mais alcalino e valores altos de condutividade na água, afetando o desenvolvimento das plantas (SCHOSSLER et al., 2012). As amostras com maiores concentrações de sódio são as P3 e P1, enquanto que a P5 apresenta a menor concentração (tabela 2). Nos demais elementos químicos pode haver indicadores de poluentes, mesmo que seja em quantidades reduzidas.

Já o óxido de ferro ocorre nas rochas como componente principal de muitos minerais primários, sobretudo, em rochas compostas por olivinas, piroxênios e anfibólios (CORRÊA, 2004). Desse modo, piroxênios e anfibólios estão presentes nas unidades geológicas Complexo Riacho do Tigre e Suíte Intrusiva Itaporanga, conforme o relatório Pesqueira do Serviço Geológico do Brasil (2015). Nessas unidades estão presentes respectivamente os pontos 3 , 4 e na última unidade o ponto 5 , que tiveram proporções inferiores de óxido de ferro em relação aos pontos 1 e 2 (tabela 2). O P1 está situado na unidade geológica Granitóide de Serra da Barraca, a qual possui rochas desenvolvidas por minerais ferromagnesianos (CPRM, 2000), o que poderia estar relacionada à porcentagem maior de óxidos de ferro e magnésio nesse trecho em relação aos demais. Apesar da pequena proporção do óxido de ferro nas amostras (inferior a $3 \%$ ) e de pequenas variações de proporções entre todos os pontos (inferior a 1\%), o aprofundamento dessas informações pode ser de alta relevância em pesquisas futuras para a região, principalmente no intuito de investigar o motivo pelo qual a porcentagem de ferro é maior no P2 em relação aos P3, P4 e P5.

É notável que a maior diversidade de elementos ocorre no trecho 3 , enquanto que a menor ocorre no trecho 5. Essa observação pode estar relacionada com a localização dos pontos na bacia (figura 1), visto que o trecho 3 está numa confluência próxima à foz, a qual pode haver sedimentos depositados advindos de fluxos distintos, que foram remobilizados e transportados de diferentes áreas da bacia com declividade mais elevada. Já o trecho 5, como está situado próximo a nascente, os sedimentos não sofreram o mesmo processo de transporte e remobilização do que os outros trechos, ocorrendo esse processo numa intensidade bem menor, portanto, essa diversidade de óxidos acompanha maior variedade em áreas de maior captação hídrica. Devido a localidade do trecho 5 (área fonte de sedimentos), não 
há grande diversidade de elementos provenientes de outras unidades, por outro lado, os sedimentos dessa unidade podem ser transportados à jusante.

Embora alguns metais sejam essenciais para o desenvolvimento dos processos bioquímicos, quando eles apresentam determinadas concentrações podem ser considerados como tóxicos, como cobre (Cu) e zinco (Zn). Entretanto, esses metais citados juntamente com os metais não essenciais - como antimónio (Sb), arsênio $(\mathrm{As})$, chumbo $(\mathrm{Pb})$, cádmio $(\mathrm{Cd})$ e crômio $(\mathrm{Cr})$ - são poluentes ambientais que podem influenciar de maneiras irreversíveis em relação aos processos fisiológicos e bioquímicos (SOUSA, 2010). A classificação do material a ser dragado em águas jurisdicionais brasileiras (Resolução do CONAMA n ${ }^{\circ} 344$ de 25 de março de 2004) contém variações dos níveis de metais pesados, como cádmio, chumbo, cobre, cromo (ou crômio), níquel, zinco e mercúrio, porém, entre todos esses metais citados, somente o crômio $(\mathrm{Cr})$ foi identificado, na amostra P3, correspondente ao trecho 3 .

A resolução $n^{\circ} 344$ do CONAMA de 25 de março de 2004 prevê dois níveis referentes aos critérios de qualidade do material a ser dragado: nível 1, corresponde ao limiar abaixo do qual se prevê baixa probabilidade de efeitos adversos a biota; e o nível 2 corresponde ao limiar acima do qual se prevê um provável efeito adverso a biota. Os valores de classificação (em unidade de material seco) para o crômio $(\mathrm{Cr})$ nas águas doces são de $37,3^{1} \mathrm{mg} / \mathrm{kg}$ para o nível 1 e $90^{1} \mathrm{mg} / \mathrm{kg}$ para o nível 2; para as águas salobras e salinas, os valores são de $81^{2}$ $\mathrm{mg} / \mathrm{kg}$ para o nível 1 e $370^{2} \mathrm{mg} / \mathrm{kg}$ para o nível 2 .

Todavia, as técnicas utilizadas nessa pesquisa não permitem a quantificação dos poluentes em $\mathrm{mg} /$ $\mathrm{kg}$ de material seco (assim como na resolução do CONAMA). No entanto, essas informações servem de alerta para a presença do crômio no material do trecho 3 (embora seja em pequena proporção). Dependendo de sua concentração, o crômio pode ser tóxico aos seres humanos, podendo causar corrosão do aparelho digestivo, hemorragia interna, náuseas, diarreias e danos aos rins, fígado e pulmões. A cromita $\left(\mathrm{FeCr}_{2} \mathrm{O}_{4}\right)$ é o principal mineral de ocorrência do crômio (TRINDADE, et al., 2012).

Em relação às fases mineralógicas das amostras, foram considerados, sobretudo, os picos com intensidade próxima, igual ou superior a 100. 0 trecho 1 (figura 3) apresenta picos característicos com predominância de $\mathrm{SiO}_{2}$, de $\mathrm{Al}_{2} \mathrm{SiO}_{5}$ e de $\mathrm{Al}_{2} \mathrm{O}_{3}$.

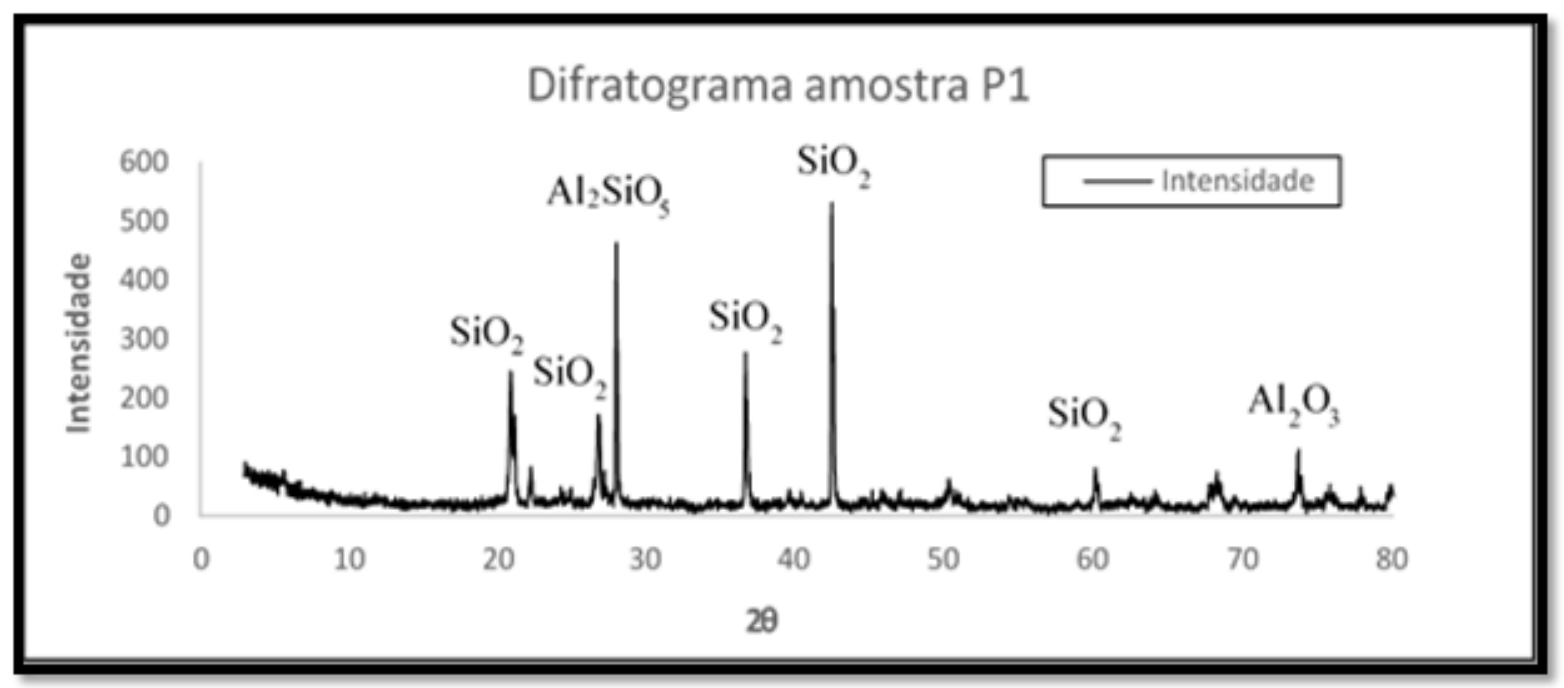

Fonte: Elaborado pelos autores.

A sílica existente no difratograma da amostra P1 corresponde às fases mineralógicas do quartzo-a. No semiárido, a formação geológica geralmente demonstra ser rica em quartzo (CORREIA et al., 2011), justificando a sua predominância nas amostras. Em todos os pontos há predominância de $\mathrm{SiO}_{2}$, conforme revela a tabela 2 , porém, existem diferentes variedades da sílica, as quais as principais são o quartzo, tridimita e cristobalita. Essa variedade está relacionada aos intervalos de temperatura das diferentes fases cristalinas estáveis da sílica à pressão atmosférica. 0 quartzo-a se transforma em quartzo- $\beta$ quando a temperatura supera $573^{\circ} \mathfrak{C}$, a pressão atmosférica; nessa sequência, o quartzo- $\beta$ se transforma em tridimita a partir de $870^{\circ} \mathrm{C}$; e a tridimita se transforma em cristobalita a partir de $1470^{\circ} \mathrm{C}$; e quando a temperatura chega em $1710^{\circ} \mathrm{C}$ é onde se tem a forma líquida da sílica (FERNANDES, 2012; GOMES, FURTADO e SOUZA; 2018).

A presença do óxido de alumínio no difratograma pode estar associada ao intemperismo do granito, que 
basicamente possui em média $72 \%$ de sílica e $14 \%$ de alumínio (BLATT e TRACY, 1996). Desse modo, o ponto 1 está situado na unidade Granitóide de Serra da Barraca, conforme a carta geológica de Sumé, a qual é constituída essencialmente por granitos, além de plagioclásio, microclina, quartzo e biotita, podendo variar o percentual de hornblenda, ferro-hastingsita e diopsídio-hedenbergita (CPRM, 2000).

O último pico de difração antes do ângulo 30 corresponde à cianita, um mineral com alta porcentagem de óxido de alumínio, com a forma geral $\mathrm{Al}_{2} \mathrm{SiO}_{5}$. A cianita geralmente ocorre como agregados cristalinos em xistos aluminosos, paragnaisses e quartizitos situados em terrenos metamorfizados em zonas de deformação de alta pressão, como por exemplo, as zonas de cisalhamento. Os protolitos com alta concentração de alumina (rochas sedimentares finas, paleoregolito ou as zonas de alteração hidrotermal) são responsáveis pela formação de rochas com concentrações elevadas de cianita (JOFFILY e OLIVEIRA, 2008).

A bacia Riacho do Tigre (especificamente na unidade geológica Complexo Riacho do Tigre) é constituída por biotita, xistos granatíferos, gnaisses xistosos e paragnaisses, com atuação metamórfica, portanto, apresenta condições reais para ocorrência da cianita. Entretanto, o P1 não está situado na unidade Complexo Riacho do Tigre, referente ao Projeto Pesqueira (CPRM,
2015) - embora esteja bem próximo - mas sim na unidade Granitóide de Serra da Barraca, referente ao Projeto Sumé, cujas rochas geralmente são constituídas por granitóides, litótipos quartzo-monzoníticos, quartzodioríticos e leucogranitos, com foliação tectônica incipiente, sobretudo, desenvolvida por minerais ferromagnesianos (CPRM, 2000).

Nesse caso, os sedimentos correspondentes à amostra P1 podem ser oriundos de uma parte da unidade Complexo Riacho do Tigre (figura 2), que fica nas cabeceiras a montante do trecho 1 (CPRM, 2015), onde possivelmente os sedimentos dessa unidade teriam sidos depositados no leito e depois remobilizados e transportados pelo fluxo do canal. Isso é mais uma questão que pode ser melhor investigada em futuras pesquisas, sobretudo, em pesquisas voltadas às técnicas de rastreamento das fontes de sedimento através do material transportado na rede de drenagem.

Para o trecho 2, o difratograma da amostra P2 aponta somente dois consideráveis picos de difração, ambos correspondentes ao óxido de silício $\left(\mathrm{SiO}_{2}\right)$, conforme mostra a figura 4. 0 pico com menor intensidade corresponde ao quartzo, e o pico de maior intensidade corresponde ao mineral tridimita. 0 trecho 2 possui $83 \%$ da proporção de $\mathrm{SiO} 2$ na amostra, sendo o segundo ponto com maior proporção desse óxido entre todos os outros analisados.

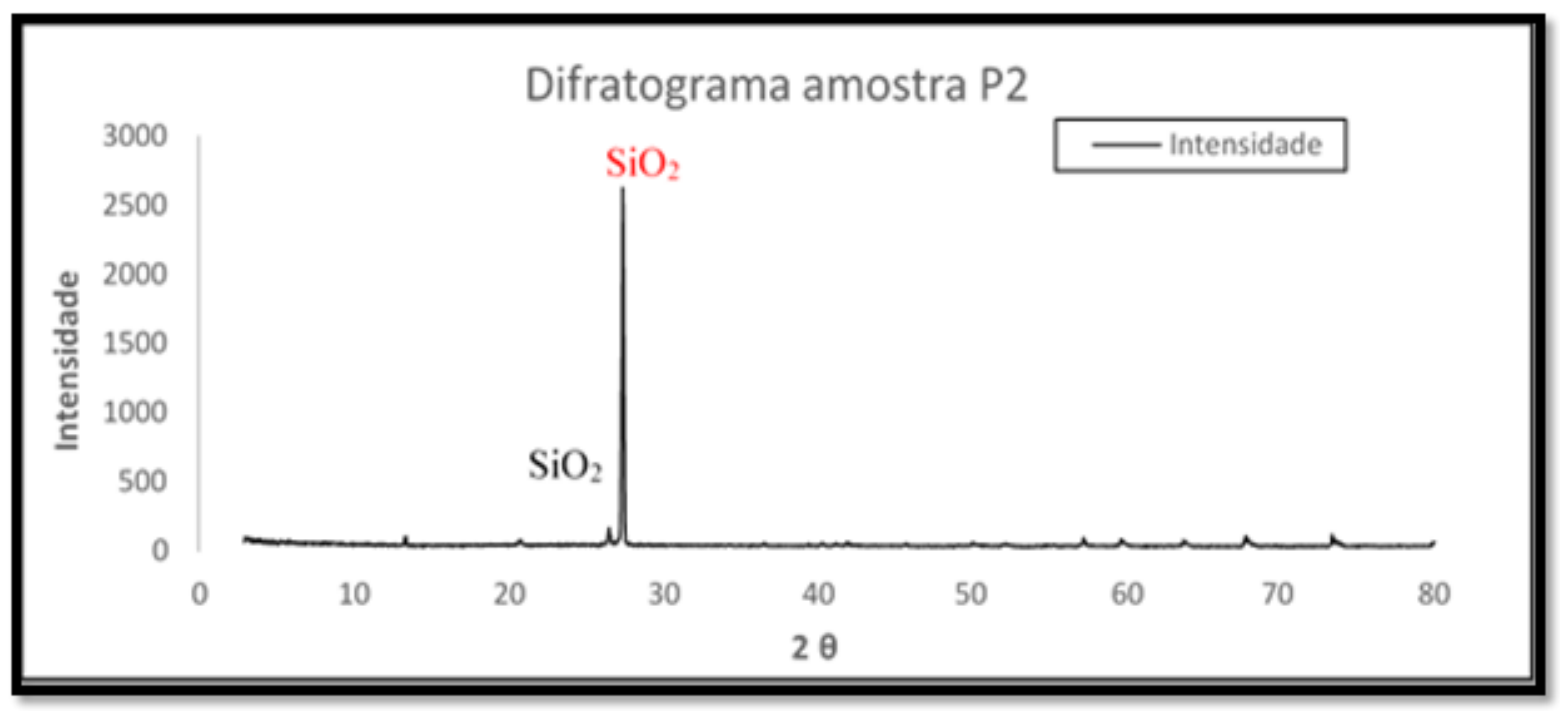

Fonte: Elaborado pelos autores.

A grande quantidade de sílica na amostra pode ofuscar a presença de outros componentes, dificultando a identificação de outros picos de difração correspondentes às fases mineralógicas de outro material. No entanto, a alta intensidade do segundo pico de difração indica que a maior parte da sílica existente no trecho 2 está relacionada com presença da tridimita, diferente do trecho 1 cuja totalidade da sílica corresponde unicamente ao quartzo.

O trecho 2 está situado na unidade Suíte Intrusiva Metagranitóides Cariris Velhos, composta por metagranitóides peraluminosos de composição monzogranítica (CPRM, 2015). Todavia, a tridimita e cristobalita não ocorrem em rochas plutônicas, mas sim 
em rochas vulcânicas (intermediárias a ácidas), como andesitos, dacitos e riolitos (VLACH, 2002).

A unidade Complexo Riacho do Tigre é composta por rochas intermediárias a ácidas, podendo variar de composição andesítica a riolítica (CPRM, 2015). Logo, a ocorrência da tridimita no trecho 2 talvez possa estar associada aos sedimentos depositados nas drenagens localizadas próximas de uma parte leste da unidade Complexo Riacho do Tigre - no limite da delimitação da bacia (figura 2) - proveniente das serras que ficam a montante dos trechos 1 e 2, cujos sedimentos poderiam ter sidos transportados pela rede de drenagem e depositados no leito. Outra hipótese seria a alta intensidade da influência antrópica nesta área, contendo algumas construções humanas, como cacimbas, poços, cercas e atividades como agricultura, irrigação e pecuária nas proximidades.

0 trecho 3 apresentou variedade de intensidade de picos característicos associados a diferentes materiais. Assim, como mostra na figura 5 , os picos de difração identificados são de quartzo $\left(\mathrm{SiO}_{2}\right)$, cromita $\left(\mathrm{FeCr}_{2} \mathrm{O}_{4}\right)$, albita $\left(\mathrm{NaAlSi}_{3} \mathrm{O}_{8}\right)$ e coríndon $\left(\mathrm{Al}_{2} \mathrm{O}_{3}\right)$. Diferente do trecho anterior, o trecho 3 não possui picos de tridimita, ou seja, a quantidade de $\mathrm{SiO} 2$ corresponde somente ao quartzo, assim como no trecho 1 .

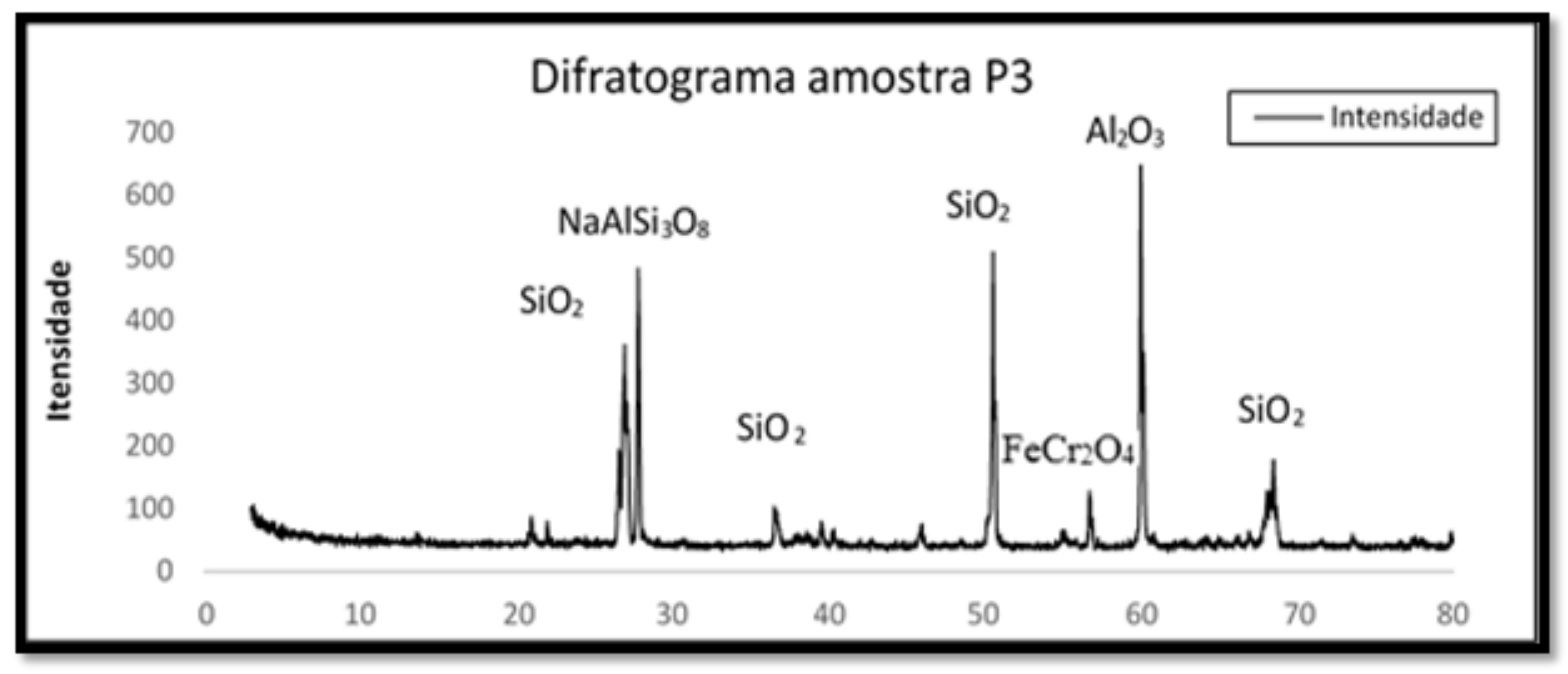

Fonte: Elaborado pelos autores.

A presença de cromo no trecho 3 (indicada pela análise de FRX) tem relação com a presença da cromita, constatada a partir da análise de DRX. A cromita $\left(\mathrm{FeCr}_{2} \mathrm{O}_{4}\right)$ é um mineral que se constitui como a principal fonte do cromo. Os depósitos de cromita se originam principalmente em rochas básicas e rochas ígneas máficas (SAMPAIO, ANDRADE e PAIVA, 2008). Logo, na unidade geológica - Complexo Riacho do Tigre - em que o trecho 3 se encontra, há presença de ortognaisses relacionados às rochas máficas e rochas metavulcânicas (CPRM, 2015), o que talvez esteja associada à ocorrência da cromita neste trecho.

0 coríndon é um mineral de óxido de alumínio (Al2O3) que tem variedades gemológicas como rubi (do latim rubeus $=$ vermelho) e safiras $($ do grego $=$ azul), além de ser o segundo mineral de maior dureza, atrás somente do diamante, porém, estima-se que somente $1 \%$ do coríndon minerado no mundo inteiro seja aproveitável gemologicamente (LICCARDO, 2003). Liccardo (2003) apontou 29 ocorrências de coríndon no Brasil, sendo a maioria encontrada em depósitos aluviais. No Nordeste as ocorrências são majoritariamente na Bahia e uma no semiárido paraibano, no município de Patos. Contudo, Gomes (2001) apontou evidências da ocorrência do coríndon nos municípios de Serra Talhada-PE e Cachoeira dos Índios-PB, também no semiárido nordestino.

De forma geral, é comum a presença de coríndon em rochas metamórficas, como gnaisses e micaxistos, as quais não se configuram como minério precioso, podendo também ser encontrado como constituinte de algumas rochas ígneas com baixo teor de sílica (LICCARDO, 2003). Portanto, na unidade geológica em que se encontra o trecho 3 (Complexo Riacho do Tigre), há rochas de origens metamórficas que possam haver coríndons, como os gnaisses, gnaisses xistosos e rochas constituídas por minerais como granada e biotita. Além disso, materiais de outras unidades geológicas podem ter sidos depositados nas drenagens a montante do trecho 3 e remanejados até este trecho: ao norte da montante do $\mathrm{P} 3$, no riacho do Tigre, na unidade Suíte Intrusiva Itaporanga (geralmente áreas com valores de altitude superior a $1000 \mathrm{~m}$ ), há presença de quartzo-coríndon 
hiperstênio normativas; e ao leste da montante do P3, no riacho Cacimbinha, na unidade Metagranitóides Cariris Velhos, há rochas peraluminosas com minerais ricos em alumina na rocha, como coríndon normativas (CPRM, 2015).

Assim, a presença do óxido de alumínio representa origens diferentes nos difratogramas dos trechos 1 e 3 , sendo a do trecho 3 correspondente ao mineral coríndon, enquanto que no trecho 1 foi identificado apenas 0 óxido de alumínio ao invés de picos de minerais de alumínio, provavelmente em função da ocorrência do intemperismo das rochas graníticas.

A identificação albita $\left(\mathrm{NaAlSi}_{3} \mathrm{O}_{8}\right)$ pode estar relacionada com a concentração de sódio do trecho 3 , que é a mais alta entre todos os pontos de análise. A albita é um feldspato de sódio da série do plagioclásio.
Por sua vez, os pegmatitos são a fonte principal do feldspato em função de sua pureza, abundância e cristais, cujos principais depósitos de pegmatitos do Brasil estão situados na província da Borborema (semiárido nordestino) e no oeste de Minas Gerais (LUZ, LINS e COELHO, 2008). Desse modo, na unidade Complexo Riacho do Tigre, onde o P3 se encontra, tem a presença de minerais félsicos, essencialmente plagioclásio e quartzo (CPRM, 2015).

O difratograma dos materiais do trecho 4 apresentou variedade e intensidades de picos de difração característicos do $\mathrm{SiO}_{2}$ (figura 6). Praticamente todos os picos de difração da amostra $\mathrm{P} 4$ correspondem ao $\mathrm{SiO}_{2}$. A proporção da quantidade desse óxido para o trecho 4 demonstrou ser a terceira maior entre todos os trechos de análise, ficando atrás somente do trecho 5 e 2.

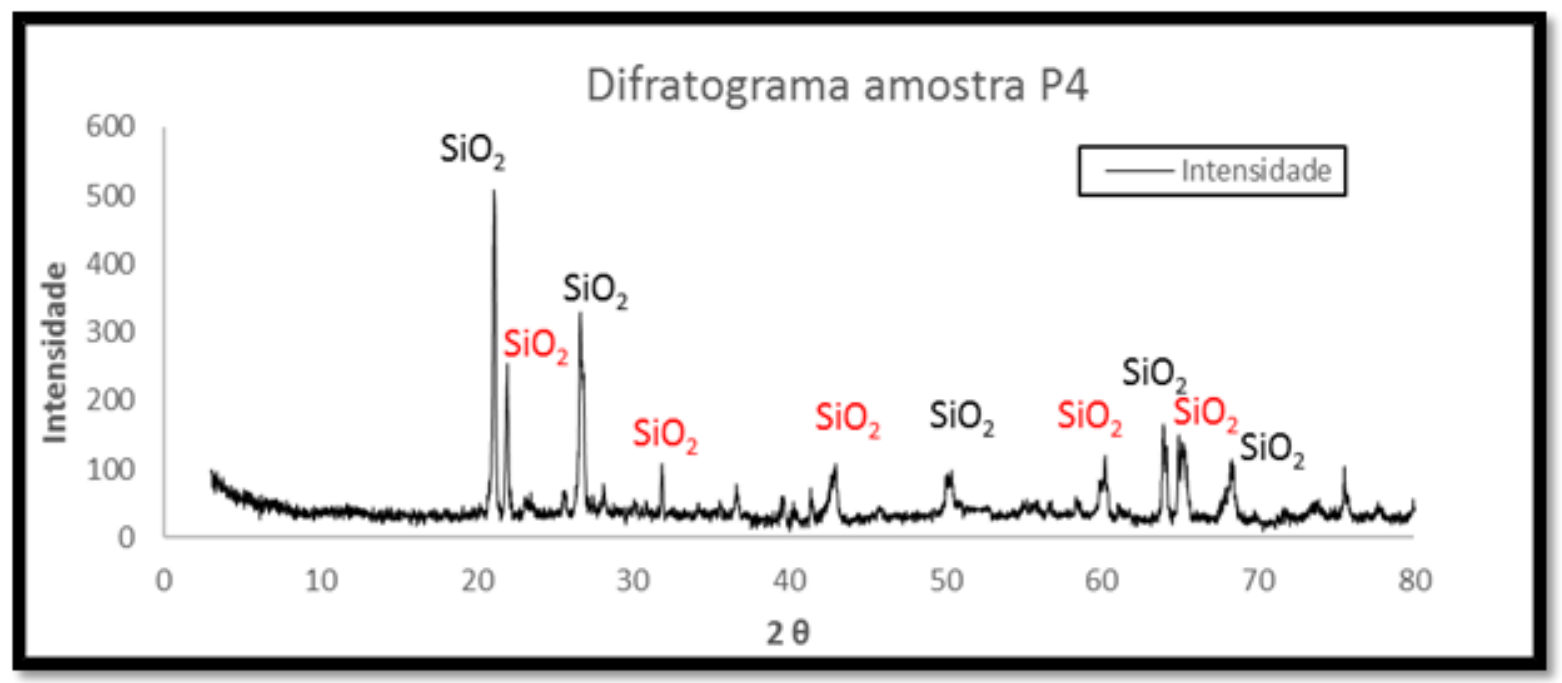

Fonte: Elaborado pelos autores.

Os picos de difração com que representam o $\mathrm{SiO}_{2}$ com a cor vermelha corresponde ao mineral cristobalita, enquanto que 0 restante corresponde ao quartzo (figuras 6). Logo, as informações obtidas da amostra P4 revelam semelhança ao trecho 2 , na qual ambos tiveram concentrações elevadas de $\mathrm{SiO}_{2}$, de modo que essa predominância pudesse ter inibido a detecção de outros elementos a partir da DRX. As únicas diferenças entre os pontos 4 e 2 é que a amostra P4 apresentou maior diversidade de picos de difração, além da identificação da cristobalita ao invés da tridimita.

o mineral cristobalita pode ocorrer em rochas vulcânicas básicas a acidas (do basalto ao riolito), assim como em rochas sedimentares silicosas (NAVARRO et al., 2017). Desse modo, a unidade geológica Complexo
Riacho do Tigre, onde está situado o trecho 4, possui rochas vulcânicas intermediárias a félsicas (ácidas) que variam de composição andesítica a riolítica, além de algumas rochas metamórficas de origem ígnea, com variações de sílica correspondentes entre rochas intermediárias a máficas, como metandesitos e metabasaltos, respectivamente (CPRM, 2015).

No trecho 5 houve variações dos picos de difração com elementos diferentes. Entretanto, os picos com maior intensidade correspondem ao $\mathrm{SiO}_{2}$, associados também à grande quantidade desse óxido na amostra $\mathrm{P} 5$, pois este é o trecho onde há maior concentração de SiO2 entre todas as amostras. 0 outro elemento identificado com intensidade de picos menor (na faixa de 100 a 200) é o $\mathrm{Fe}_{3} \mathrm{O}_{4}$ (figura 7). 


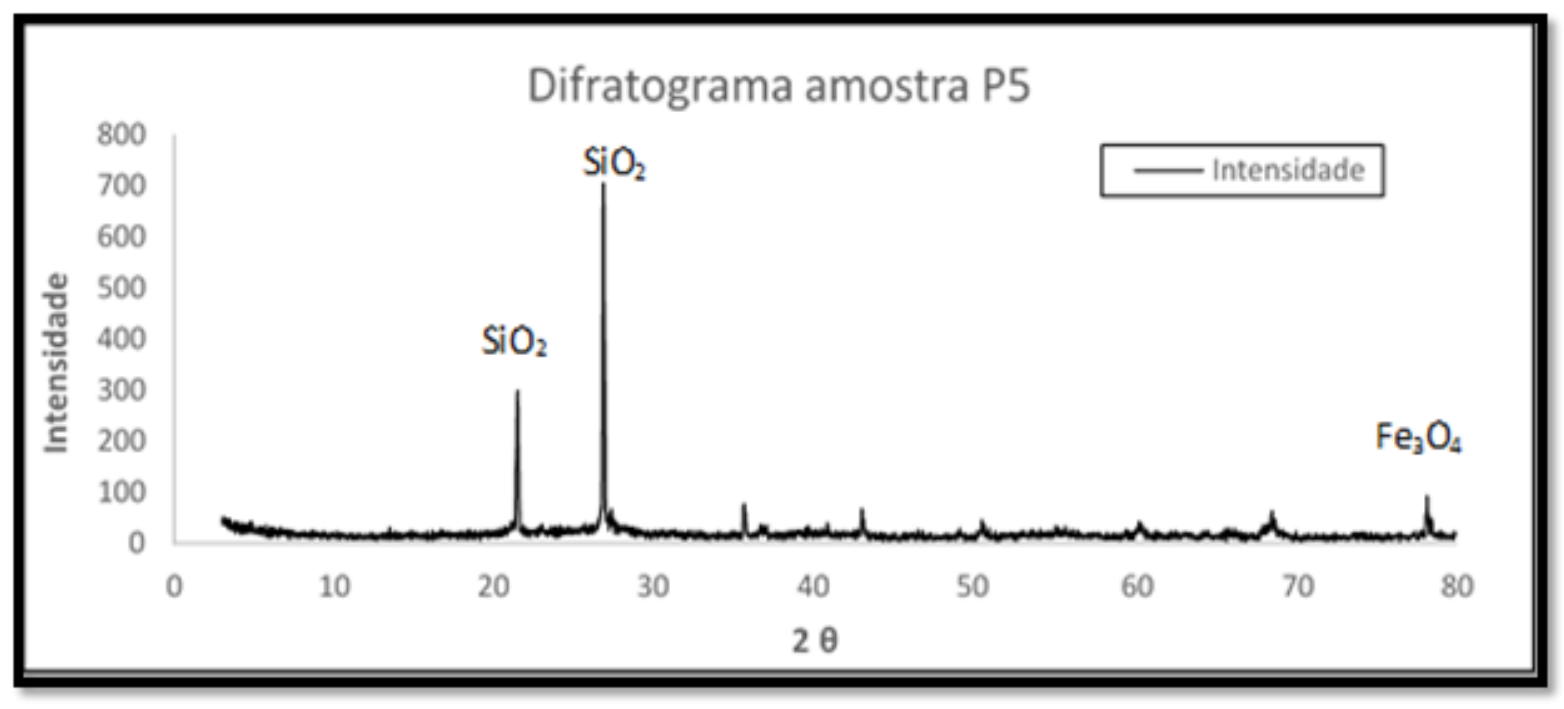

Fonte: Elaborado pelos autores.

0 último elemento identificado por DRX nos sedimentos do trecho 5 (Fe3O4) corresponde ao mineral magnetita. A magnetita é um dos principais óxidos de ferro (ferrimagnéticos) de ocorrência em solos, sobretudo, em solos desenvolvidos de vários materiais de origem, principalmente de materiais provenientes de rochas máficas. Nas fases de intemperismo, esse mineral tende a se acumular nas frações mais grosseiras dos solos, além de ser uma das mais importantes fontes de elementos traço no solo (CAMÊLO, 2013). Contudo, o P5 se encontra na unidade geológica Suíte Intrusiva Itaporanga, que possui feições magnéticas que talvez estejam relacionadas às variações faciológicas, revelando áreas mais ricas em fases minerais com afinidade ao ferro, além de ocorrência de alguns minerais máficos nas rochas, principalmente biotita e anfibólio (CPRM, 2015).

Analisando os trechos de forma geral, observou-se que a maior variedade de minerais identificados corresponde ao trecho 1 e principalmente ao trecho 3 , este que possui a maior área de captação hídrica entre todos os trechos, e consequentemente, uma maior variedade de litologias fonte dos sedimentos.

0 trecho 1 possui área de captação menor que os trechos 2 e 4, porém apresentou maior diversidade de minerais identificados do que estes dois. Talvez isso possa estar associado a alguns fatores como: as características da unidade geológica aos quais pertencem os trechos 2 e 4 (Complexo Riacho do Tigre); a porcentagem maior de óxido de silício desses trechos em relação ao trecho 1; ou a fatores de natureza antrópica. Essas questões que podem ser melhor investigadas à posteriori, a partir do monitoramento da área e de outras possíveis técnicas.

Os trechos 2 e 4 obtiveram predominância absoluta de minerais compostos essencialmente por óxido de silício, como o quartzo e seus polimorfos tridimita (no trecho 2) e cristobalita (no trecho 4). E no trecho 5, a grande quantidade de óxido de silício talvez tenha ofuscado a identificação de outros óxidos (assim como pode ter acontecido nos trechos 2 e 4) - já que foi observado que as amostras que obtiveram menores porcentagens de óxido de silício (P1 e P3) tiveram maior variedade mineralógica identificada nos picos de difração. Porém, no trecho 5 a sílica corresponde somente ao quartzo e também foi possível identificar outro mineral, que é a magnetita, apesar de apresentar pico de difração com baixa intensidade.

\section{Considerações finais}

As análises químicas e mineralógicas dos sedimentos revelaram a presença de 13 óxidos em relação aos cinco trechos, com proporção variada, alguns com mais tipos de óxidos e outros com menos, sendo o trecho 3 o que apresenta maior diversidade de elementos e também o único trecho com presença de metal pesado $(\mathrm{Cr})$. A análise por DRX mostrou a variabilidade mineralógica existente entre todos os trechos, sendo o P1 e P3 os trechos com maior diversidade mineralógica.

Os minerais identificados coincidem com as características geológicas, litoestratigráficas e litológicas da bacia Riacho do Tigre, portanto, as informações obtidas se encontram no padrão de normalidade para todos os trechos analisados. Além disso, essas informações podem ser aperfeiçoadas com 
a possibilidade de realização da técnica "fingerprinting", no intuito de relacionar, com maior precisão, os depósitos aluviais analisados nas drenagens com as fontes de produção de sedimentos identificadas. Os dados de análises químicas e mineralógicas em depósitos aluviais do semiárido são escassos até o momento, sobretudo, quando os mesmos são direcionados a uma perspectiva ambiental e de utilização de recursos hídricos por via de poços. 


\section{Referências}

AlBERS, A. P. F.; MELCHIADES, F. G.; MACHADO, R.; BALDO, J. B.; BOSCHI, A. O. (2002) Um método simples de caracterização de argilominerais por difração de raios X. Cerâmica 48 (305) Jan/Fev/Mar.

ARAÚJO, A. D.; FREITAS, M. O.; MOURA, L. C.; BAGGIO FILHO, H.; CAMBRAIA, R. P. (2017) Avaliação geoquímica ambiental do garimpo Areinha: Estudo da concentração e distribuição de metais pesados nos sedimentos e os danos à saúde humana. Hygeia, 13 (26), p. 98-113.

BLATT, H.; TRACY, R. J. (1996) Petrology: igneous, sedimentary and metamorphic. 2nd ed. New York: Freeman, 529p. ISBN 0-7167-2438-3.

BRASIL. (2004) Conselho Nacional do Meio Ambiente. Resolução CONAMA n³44, de 25 de março de 2004 . Diretrizes gerais e procedimentos mínimos para a avaliação do material a ser dragado em águas jurisdicionais brasileiras, e dá outras providências.

CAMÊLO, Danilo de Lima. (2013) Mineralogia, susceptibilidade magnética e teores de fósforo e de elementos traço em latossolos férricos e periféricos de Minas Gerais. Viçosa. 122 p. Dissertação de Mestrado. Programa de Pós-Graduação em Solos e Nutrição de Plantas, Universidade Federal de Viçosa.

CAMPOS, M.; DALL'OCCO, P. (2011) Diagnóstico da qualidade do sedimento na avaliação de impactos antrópicos em bacias hidrográficas. In: VII Jornada de Iniciaçao Científica, p. 1-21.

CORINGA, J. E. S.; PEZZA, L.; CORINGA, E. A. O.; WEBER, O. L. S.; SOUSA, D. (2013) Geoquímica e Mineralogia dos Sedimentos do Rio Bento Gomes, Poconé-MT. XXXIV Congresso Brasileiro de Ciência do Solo, 4 p, Florianópolis - SC. CORRÊA, A.; TAVARES, B.; MONTEIRO, K.; CAVALCANTI, L.; LIRA, D. (2010) Megageomorfologia e morfoestrutura do Planalto da Borborema. Revista do Instituto Geológico. V. 31, n. 1/2, p. 35-52.

CORRÊA, J. (2004) Mineralogia e gênese das principais classes de solos de encostas basálticas do Estado de Santa Catarina. Dissertação (Mestrado) - Universidade do Estado de Santa Catarina. Lages: UDESC. 92p.

CORREIA, R. C.; KIILL, L. H. P.; MOURA, M. S. B.; CUNHA, T. J. F.; JESUS JUNIOR, L. A.; ARAÚJO, J. L. P. (2011) A região semiárida brasileira. Disponível em: www.alice.cnptia.embrapa.br/digital/bitstream/item/54762/1/01-A-regiaosemiaridabrasileira.pdf-18-12-2011.pdf. Acesso em: 19 de nov. de 2018.

CPRM -Serviço Geológico do Brasil. (2015) Geologia e Recursos Minerais da Folha Pesqueira SC.24-X-B-II. Escala 1:100.000.Estados de Pernambuco e Paraíba. / Ana Cláudia de Aguiar Accioly [et al.]. - Recife.

CPRM - Serviço Geológico do Brasil. (2005) Projeto cadastro de fontes de abastecimento por água subterrânea. Diagnóstico do município de São João do Tigre, Estado da Paraíba. Recife: CPRM/PRODEEM.

CPRM -Serviço Geológico do Brasil. (2000) Programa Levantamentos Geológicos do Brasil. Sumé. Folha SB.24-Z-D-V. Estados da Paraíba e Pernambuco. Escala 1:100.000. / Organizado por Vladimir Cruz de Medeiros e H. Falcão Torres. Brasília.

EMBRAPA. (2009) Análise mineralógica das frações finas do solo por difratometria de raios-X. ISSN 1517-5685. Rio de Janeiro. 9p.

FERNANDES, Cristiane do Nascimento. (2012) Proposta de estudo sobre composições de porcelanato com incorporação do resíduo da extração de scheelita de Currais Novos - RN. Mossoró, 79p. Monografia apresentada á Universidade Federal Rural do Semiárido.

GOMES, L. S.; FURTADO, A. C. R.; SOUZA, M. C. (2018) A sílica e suas particularidades. Revista Virtual de Química, vol. 10, n. 4, 22 p..

GUEDES, J. A. (2012) Geoquímica e Meio Ambiente. GeoTemas, Pau dos Ferros, Rio Grande do Norte, Brasil, v. 2, n. 1, p. 145-151.

IBGE - Instituto Brasileiro de Geografia e Estatística. Cidades / Paraíba. Disponível em:<http://cidades.ibge.gov.br/xtras/ perfil.php?lang=\&codmun=251410\&search=|linfogr\%E1ficos:-informa\%E7\%F5es-completas>. Acesso em: 28 mar. 2016.

JOFFILY, C. M. L. C.; OLIVEIRA, C. G. (2008) Capítulo 17: Cianita Refratária. In: LUZ, A. B.; LINS, F. A. F. Rochas e Minerais Industriais. 2.Ed., 974 p. - Rio de Janeiro: CETEM/MCT.

KOBAYASHI, A. D.; SILVA, M. R. F.; FIGUEIREDO, E. A.; SARMENTO, F. J. (2017) Análise de sedimentos por fluorescência de raio $X$ em reservatórios de usos múltiplos no semiárido do nordeste do Brasil. I/ Congresso Internacional da Diversidade do Semiárido: Conidis. Campina Grande-PB.

LICCARDO, Antônio. (2008) Coríndon no Brasil - ocorrências, mineralogia, química e gênese. Ouro Preto, 2003.179 p. Tese de Doutorado. Programa de Pós-Graduação em Evolução Cristal e Recursos Naturais, Universidade Federal de 
Ouro Preto.

LUZ, A B.; LINS, F. A. F.; COELHO, J. M. Capítulo 21: Feldspato. In: LUZ, A. B.; LINS, F. A. F. Rochas e Minerais Industriais. 2.Ed., 974 p. - Rio de Janeiro: CETEM/MCT.

MELO, Rhaissa Francisca Tavares de. (2014) Evolução dos depósitos de encosta no leque Malaquias e lagoa das Pedras no entorno do maciço estrutural da serra de Água Branca. Recife. 158 p. Dissertação de Mestrado. Programa de PósGraduação em Geografia, Universidade Federal de Pernambuco.

NAVARRO, G. R. B.; ZANARDO, A.; MONTIBELLER, C. C.; LEME, T. G. (2017) Livro de referência de minerais comuns e economicamente relevantes: tectossilicatos. Museu de Minerais, Minérios e Rochas

"Prof. Dr. Heinz Ebert", 4 p., UNESP, Rio Claro. In: <https://museuhe.com.br/site/wp-content/uploads/2018/04/Museu-HE-CRISTOBALITA.pdf>. Acesso em 12 de abril de 2019.

NUNES FILHO, J.; SOUZA, A. R.; SÁ, V. A. L.; LIMA, B. P. (2000) Relações entre a concentração de íons e a salinidade de águas subterrâneas e superficiais, visando à irrigação, no sertão de Pernambuco. Revista Brasileira de Engenharia Agrícola e Ambiental, v.4, n.2, p. 189-193.

PIRES, M. A. F.; KATSUOKA, L.; COTRIM, M. E. B.; MARQUES, N.; LEMES, M. J.; DANTAS, E. S. K. (2001) Relação da atividade agropecuária na qualidade dos sedimentos fluviais de áreas de captação de água, em municípios pertencentes à bacia hidrográfica do rio Pardo. Sociedade Brasileira de Geoquímica - SBGq VII brasileiro de Geoquímica I Simpósio de Geoquímica dos países do Mercosul. P. 57-63.

ROHDE, G. M. Geoquímica Ambiental e estudos de impacto. (2013) Editora Oficina de Textos, São Paulo - SP - Brasil, $4^{\circ}$ Ed., 159p..

SAMPAIO, J. A.; ANDRADE, M. C.; PAIVA, P. R. P. (2008) Capítulo 18: Cromita. In: LUZ, A. B.; LINS, F. A. F. Rochas e Minerais Industriais. 2.Ed., 974 p. - Rio de Janeiro: CETEM/MCT.

SANTOS, E. S.; GAMA, E. M.; FRANÇA, R. S.; SOUSA, A. S.; MATOS, R. P. (2013) Espectrometria de Fluorescência de Raios - X na determinação de espécies químicas. Enciclopédia biosfera, Centro Científico Conhecer - Goiânia, v.9, n.17, p. 3413-3432.

SCHOSSLER, T. R.; MACHADO, D. M.; ZUFFO, A. M.; ANDRADE, F. R.; PIAUILINO, A. C. (2012) Salinidade: os efeitos na fisiologia e na nutrição mineral de plantas. Enciclopédia Biosfera, Centro Científico Conhecer, Goiânia, v. 8 n. 15; p. 15631578.

SILVA, Adonai Felipe Pereira de Lima; SOUZA, Jonas Otaviano Praça de. (2017) CARACTERIZAÇÃO HIDROSSEDIMENTOLÓGICA DOS TRECHOS ALUVIAIS DA BACIA RIACHO DO TIGRE - PB. Caminhos de Geografia, [S.I.], v. 18, n. 63, p. 57-89, set. 2017. ISSN 1678-6343. Disponível em: <http://www.seer.ufu.br/index.php/caminhosdegeografia/ article/view/36159>. Acesso em: 05 mar. 2018. doi :http://dx.doi.org/10.14393/RCG186303.

SOUSA, Joana Manoela Dias de. (2010) Exposição a metais pesados no ambiente de trabalho: estabelecimento de bioindicadores de exposição a poluentes. 71 p. Dissertação de Mestrado. Departamento de biologia animal. Universidade de Lisboa.

TRINDADE, W. M.; HORN, A. H.; RIBEIRO, E. V. (2012) Concentrações de metais pesados em sedimentos o rio São Francisco em Três Marias e Pirapora-MG: geoquímica e classificação de risco ambiental. Geonomos, 20 (1), p. 64-75. VASCONCELOS, J. O.; SOUZA, J. O. P. (2016) Zoneamento e caracterização da bacia hidrográfica de São João do Tigre. Revista de Geociências do Nordeste, V. 2, p. 171-180.

VLACH, S. R. F. (2002) A classe dos tectossilicatos: guia geral da teoria e exercício. Revista do Instituto de Geociências - USP, vol. 1, $44 \mathrm{p}$. 